\title{
Serum Human Epididymis Protein 4 (HE4) As A Diagnostic And Follow-Up Biomarker in Patients With Non-Small Cell Lung Cancer
}

\author{
Ulas KUMBASAR ${ }^{1}$, Zeliha G. DIKMEN², Yigit YILMAZ ${ }^{3}$, Burcu ANCIN³, \\ Erkan DIKMEN ${ }^{3}$, Riza DOGAN ${ }^{1}$ \\ ${ }^{1}$ Hacettepe University School of Medicine, Cardiovascular and Thoracic Surgery Department
${ }^{2}$ Hacettepe University School of Medicine, Department of Medical Biochemistry
${ }^{3}$ Hacettepe University School of Medicine, Department of Thoracic Surgery, Ankara, TURKEY
}

ABSTRACT

Early detection of non-small cell lung cancer (NSCLC) cases is crucial since nearly one third of them are unresectable during diagnosis and also the recurrence rates are high following treatment. Thus, in this study we aimed to evaluate both the diagnostic performance and the post-resection progress of serum Human epididymis protein 4 (HE4) in patients with NSCLC. Thirty-one patients who had benign lung disease (group 1) were matched to the same number of patients with resectable NSCLC (group 2). Serum HE4 levels were measured at the time of diagnosis and following surgery - at post-operative 1st month (only in group 2). The serum HE4 in NSCLC group was significantly higher than that of the benign group (89.70 (58.10-397.00) pmol/L and 42.60 (28.10-198.90) pmol/L, respectively; $p<0.001)$. HE4 levels in NSCLC group were significantly decreased from 89.70 (58.10-397.00) to 71.50 (41.70-232.30) pmol/L following pulmonary resection ( $p<0.001$ ). In advanced stages (III and IV) the decrease in serum HE4 levels (25.30 (10.50-164.70) was significantly higher than the decrease in early stages (I-II, 14.60 (-14.20-133.60); $p=0.025)$. ROC analysis showed the area under the curve (AUC) of HE4 was 0.921 (95\% Cl, 0.843-0.998), ( $p<0.001)$ and both the sensitivity and specificity of HE4 as a biomarker was $87.1 \%$. Our data demonstrated that HE4 is a potential biomarker for the diagnosis of NSCLC with high sensitivity and specificity and could also be used to detect recurrences following resection.

Keywords: HE4, Non-small cell lung cancer, Biomarker

\section{ÖZET}

\section{Küçük Hücreli Dışı Akciğer Kanserinin Tanı ve Takip Aşamasında HE4 Proteininin Etkinliğinin Değerlendirilmesi}

Küçük hücreli dışı akciğer kanserinde (KHDAK) hastaların yaklaşık üçte biri tanı anında anrezektabl olduğundan erken tanı oldukça önemlidir. Ayrıca tedavi sonrasında rekürrens oranı oldukça yüksektir. Bu çalışmanın amacı, KHDAK'da İnsan Epididimis Proteini 4'ün (HE4) preoperatif tanısal performansının ve cerrahi rezeksiyon uygulanan hastalarda postoperatif etkinliğinin belirlenmesidir. Hastalar, benign akciğer hastalığı olanlar (grup I, $n=31$ ) ve KHDAK nedeniyle cerrahi rezeksiyon uygulananlar hastalar (grup 2, $n=31$ ) olmak üzere iki ana gruba ayırılı. Cerrahi uygulanan grupta preoperatif ve postoperatif 1 . aydaki serum HE4 değerleri kaydedildi. KHDAK grubunda preoperatif dönemde ölçülen ortanca HE4 değerleri, benign grupta ölçülen değerlerden istatistiksel olarak anlamlı ölçüde yüksek bulundu (89.70 (58.10-397.00) pmol/L ve 42.60 (28.10-198.90) pmol/L, sırası ile; p< 0.001). Cerrahi uygulanan hastaların preoperatif ve postoperatif değerleri karşılaştııılığında HE4 seviyelerinin postoperatif dönemde istatistiksel olarak anlamlı şekilde düştüğü gözlendi (89.70 (58.10-397.00) ile 71.50 (41.70-232.30) pmol/L; p<0.001). Ileri evrelerdeki (evre III-IV) düşüşün erken evrelere (evre I-II) göre anlamlı derecede daha fazla olduğu görüldü (25.30 (10.50-164.70) ile 14.60 (-14.20-133.60); p= 0.025). HE4'ün tanısal etkinliği ROC analizi ile değerlendirildiğinde eğri altında kalan alan 0.921 (95\% Cl, 0.843-0.998) olarak hesaplandı ( $p<0.001)$. HE4 biyobelirtecinin hem duyarılı̆̆ı hem de özgüllüğü \%87.1 bulundu. Bu çalışmadaki bulgular HE4'ün, yüksek duyarlılık, özgüllük ve tanısal etkinliği nedeni ile tanısal olarak ve postoperatif takip ve olası nükslerin saptanmasındaki potansiyel etkinliği düşünülerek, KHDAK'da önemli bir biyobelirteç olmaya aday olduğunu göstermektedir.

Anahtar Kelimeler: HE4, Küçük hücreli dışı akciğer kanseri, Biyobelirteç 


\section{INTRODUCTION}

Lung cancer is still the leading cause of cancer related mortality worldwide. About $80 \%$ to $85 \%$ of lung cancers are non-small cell lung cancer (NSCLC) $^{1}$, and nearly one third of NSCLC cases are unresectable during diagnosis. ${ }^{2-4}$ Thus, early detection of these cases should be an essential goal in routine clinical practice. In addition, due to the relatively low sensitivity and specificity of currently available tumor markers for lung cancer such as carcinoembryonic antigen (CEA), serum cytokeratin 19 fragment (CYFRA 21-1) and neuron specific enolase (NSE), detection of potential recurrent disease is limited. ${ }^{5,6}$ With the recent advances in molecular biology, researchers have focused on identification of novel diagnostic and prognostic bio-markers of NSCLC.

Human epididymis protein 4 (HE4) is produced from whey-acidic-protein 4-disulfide core domain 2 (WFDC2) gene, which is located on chromosome 20 , in a segment frequently amplified in various cancers. ${ }^{7,8}$ Although HE4 is frequently revealed to be a diagnostic and prognostic biomarker of ovarian malignancies, high levels of HE4 have also been detected in other cancer types such as lung, breast and pancreas cancers. Indeed, WFDC2 is strongly expressed in a wide range of normal human tissues, including trachea, salivary glands, lung, prostate, pituitary gland, thyroid and kidney. ${ }^{6,9,10}$ In this study, we aimed to evaluate both the diagnostic performance and the post-resection progress of serum HE4 in patients with NSCLC.

\section{PATIENTS AND METHODS}

\section{Patients}

This study was approved by the ethical committee of Hacettepe University Medical Faculty. Serum samples were collected from 62 patients between April 2013 and September 2016. Patients were equally separated into two groups. Thirty-one patients who had benign lung disease (group 1) were matched to the patients with resectable NSCLC (group 2). The diagnoses and characteristics of both groups are shown in Table 1 and 2, respectively. Blood samples were collected from all patients at the time of diagnosis and following surgery - at

\begin{tabular}{|ll|}
\hline Table 1. Patient Diagnoses. & \\
\hline Diagnoses & $\mathbf{n}$ \\
\hline Group 1 (Benign lung disease) & \\
Bronchogenic cyst & 5 \\
Pleural effusion & 4 \\
Pneumonia & 3 \\
Pulmonary hamartoma & 4 \\
Tuberculosis granuloma & 3 \\
Bronchiectasis & 2 \\
Pseudotumor & 1 \\
Parapneumonic empyema & 1 \\
Neurofibroma & 1 \\
Intrathoracic neuroblastoma & 1 \\
Mesothelioma & 1 \\
Chest wall sarcoma & 1 \\
Mediastinal lymphoma & 1 \\
Secondary pulmonary neoplasm & 3 \\
Group 2 (NSCLC) & 16 \\
Adenocarcinoma & 15 \\
Squamous cell carcinoma & \\
\hline
\end{tabular}

\begin{tabular}{|llll|}
\hline Table 2. Patient characteristics. & & \\
\hline Characteristics & $\begin{array}{l}\text { Group 1 } \\
(\mathrm{n}=31)\end{array}$ & $\begin{array}{l}\text { Group 2 } \\
(\mathrm{n}=31)\end{array}$ & $\mathbf{p}$ \\
\hline Age (years) & $49.1 \pm 16.1$ & $53.4 \pm 8.4$ & 0.737 \\
Gender & & & 0.605 \\
Male & 17 & 20 & \\
Female & 14 & 11 & \\
Smoking history & & & 0.611 \\
Current or former & 14 & 17 & \\
Never & 17 & 14 & \\
TNM stage & & 11 & \\
I & & 10 & \\
II & & 9 & \\
III & & 1 & \\
IV & & & \\
\hline
\end{tabular}

post-operative 1st month (only in group 2). Pathologic staging was characterized according to the seventh edition of the American Joint Committee on Cancer TNM staging system.

\section{HE4 Measurement}

Blood samples were collected in serum separator tubes and were centrifuged at $1500 \mathrm{~g}$ for $10 \mathrm{~min}$ utes (Rotanta 460). Serum samples were stored at 


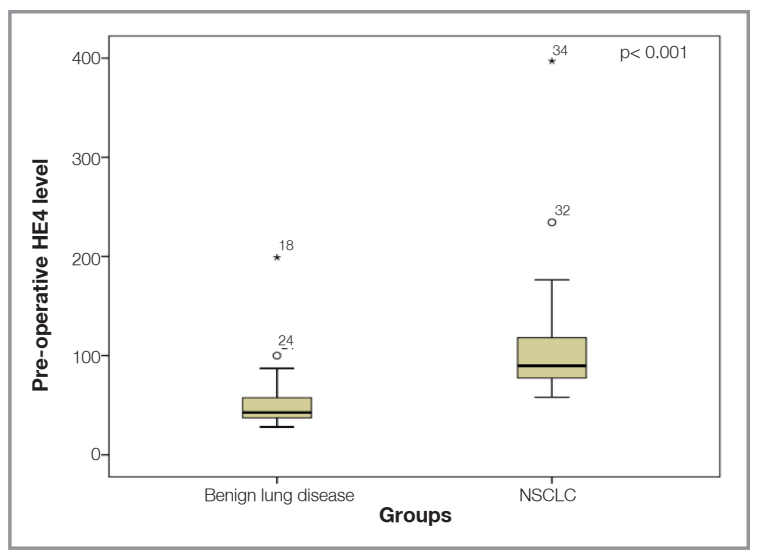

Figure 1. Pre-operative HE4 levels in both groups.

$-80^{\circ} \mathrm{C}$. HE4 levels were measured by chemiluminescent microparticle immunoassay (CMIA) using the Architect I2000 (Abbott Diagnostics, Abbott Park, IL, USA). The cut-off limit for serum HE4 was considered $70 \mathrm{pmol} / \mathrm{L}$.

\section{Statistical Analysis}

Numerical variables were evaluated for normality of data distribution by using Kolmogorov Smirnov test. Descriptive statistics were expressed as mean \pm standard deviation or median (min-max). Independent samples t-test was performed to compare the means of two groups for continuous variables. For non-normally distributed data, Mann-Whitney $\mathrm{U}$ test was used to compare two groups. Wilcoxon test was used for comparing between pre and postoperative HE4 levels. Chi-square test was used to examine the association between categorical variables.

The diagnostic performance of quantitative test (HE4 levels) was assessed by receiver operating characteristics (ROC) analysis. The ROC curve was plotted based on the true positive rate (TPR) and false positive rate (FPR). The area under the ROC curve (AUC) was calculated by using a nonparametric method. After ROC analysis, the optimal cut off point was determined using the Youden index. Sensitivity and specificity for HE4 levels were calculated according to optimal cut off point. A p value of 0.05 was accepted as statistically significant. All statistically analyses were performed by using IBM SPSS Statistics 21.0 software.

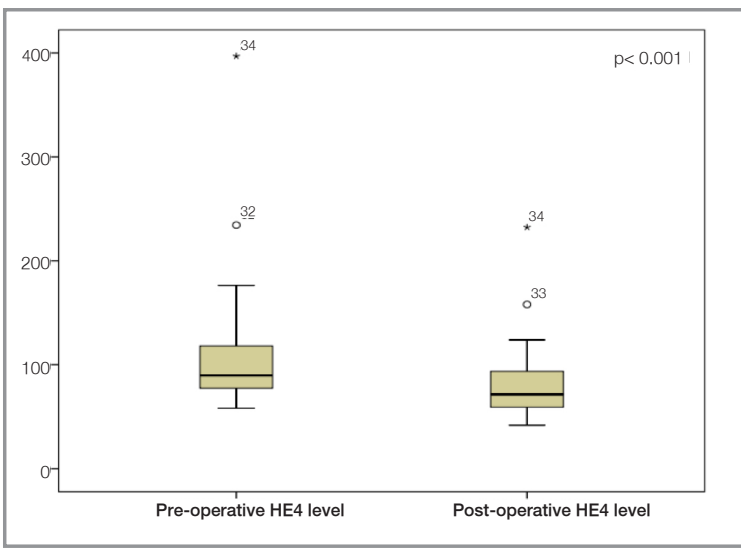

Figure 2. Comparison of pre- and post-operative HE4 levels in NSCLC group.

\section{RESULTS}

HE4 levels in patients with resected NSCLC and with benign lung disease

The serum concentration of HE4 in NSCLC group was significantly higher than that of the benign group (Figure 1). Median serum HE4 level was $89.70(58.10-397.00) \mathrm{pmol} / \mathrm{L}$ in the NSCLC group and $42.60(28.10-198.90) \mathrm{pmol} / \mathrm{L}$ in the benign group $(\mathrm{p}<0.001)$.

\section{HE4 expression in NSCLC group following pul- monary resection}

The median serum HE4 levels in NSCLC group were significantly decreased from 89.70 (58.10$397.00)$ to 71.50 (41.70-232.30) pmol/L following pulmonary resection $(\mathrm{p}<0.001$, Figure 2$)$. The reduction of HE4 levels following resection was also analyzed according to the TNM stage and histopathologic type of the tumor. In advanced stages (III and IV) the decrease in serum HE4 levels (25.30 (10.50-164.70) was significantly higher than the reduction in early stages (I-II, 14.60 (-14.20-133.60); $\mathrm{p}=0.025$, Figure 3). The histopathologic type of the tumors was observed to be not associated with HE4 reduction. Preoperative HE4 levels were almost equal in adeno and squamous cell carcinomas (99.90 (59.00-176.40) and 99.10 (69.70-165.70), respectively; $\mathrm{p}=0.572)$. HE4 reduction was 20.29 $(-3.80-59.0$ and $23.16(-14.20-80.0)$ in adeno and squamous cancers, respectively $(\mathrm{p}=0.595)$. 


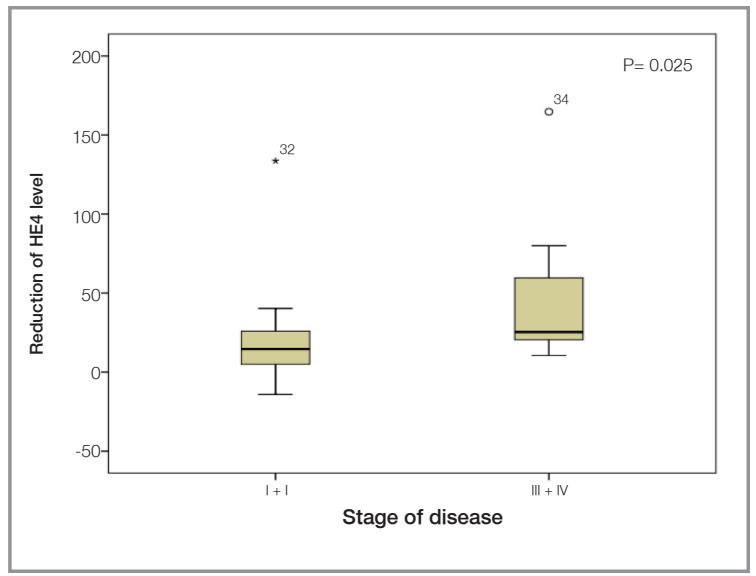

Figure 3. Comparison of HE4 levels according to the stage of the disease

\section{The diagnostic value of serum HE4 levels}

ROC analysis was performed in order to evaluate the diagnostic accuracy of HE4 levels in NSCLC patients. As shown in Figure 4, the area under the curve (AUC) of HE4 was 0.921 (95\% CI, 0.843$0.998),(\mathrm{p}<0.001)$. Both the sensitivity and specificity of HE4 as a biomarker was calculated as $87.1 \%$.

\section{DISCUSSION}

Although the prognosis of NSCLC has improved over the last decades, limited therapeutic progress has been achieved with multimodal treatment strategies in advanced stages. The cancer specific survival even in early stages is $60 \%$ to $80 \%$ with an expected 5 years recurrence rate of $30 \%$ to $55 \%$. $^{11-}$ ${ }^{13}$ Therefore, the ability to diagnose patients in early stages and to identify recurrences are important considerations to offer the best treatment options. Circulating biomarkers are promising means of both diagnosis and prognosis by screening potential NSCLC patients and detecting recurrences.

In this study, we investigated both the diagnostic role of serum HE4 in patients with NSCLC and the short-term progress of this biomarker after pulmonary resection. We found significantly higher serum levels of HE4 in patients with NSCLC compared to patients with benign lung diseases. ROC analysis, constructed using the sensitivity-specificity relationship, also revealed the potential of

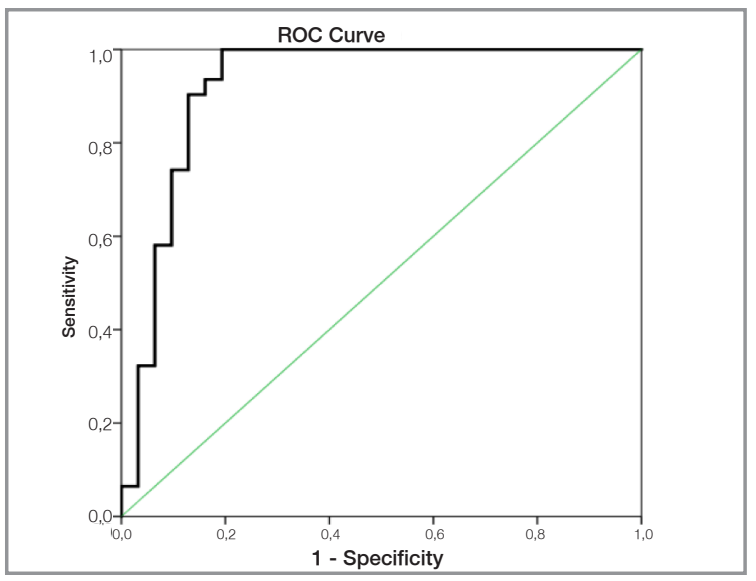

Figure 4. Diagnostic accuracy of HE4 levels

HE4 to distinguish NSCLC from benign diseases with a sensitivity of $87.1 \%$. We further evaluated the trend of serum HE4 levels in NSCLC patients after pulmonary resection and observe a significant decrease at post-operative 1 st month especially in stages III and IV.

HE4 is one of the most widely investigated of the novel biomarkers, which was first studied in patients with ovarian cancer. Since HE4 is expressed in epithelial cells of the epididymis, respiratory epithelium of proximal airways, and the normal female reproductive tract, many researchers previously indicate its use as a biomarker for NSCLC. ${ }^{7,9}$, ${ }^{14-17}$ Firstly, Yamashita et al. studied HE4 expression in lung cancer and found mainly increased levels in adenocarcinoma subtype with worse prognosis and overall survival. ${ }^{15}$ Consequently, Iwahori et al. and Liu et al. investigated the diagnostic role of serum HE4 levels in NSCLC patients and in both studies, they differentiate lung cancer patients from healthy controls with high sensitivity (89.8\%) and specificity (100\%). ${ }^{16,18}$ Recently, Cheng et al. published a meta-analysis presenting the diagnostic accuracy of HE4 in lung cancer and indicated that the sensitivity and specificity of HE4 were 0.72 and 0.85 , respectively, which are higher than the conventional biomarkers such as CEA, CYFRA21-1 and NSE. Additionally, they found that the AUC was 0.855 for HE4..$^{19,20}$ Our results regarding the diagnostic accuracy of HE4 (both sensitivity and specificity: $87.1 \%$ and AUC: 0.921 ) are much better than the results of this meta analysis, which 
indicates that HE4 is a promising biomarker for NSCLC diagnosis.

The prognostic role of HE4 in NSCLC has also been analyzed in various researches and higher levels were correlated with worse outcomes. ${ }^{2,6,15,16,21}$ Lan et al. examined the role of HE4 in the diagnosis and prognosis of patients with locally advanced NSCLC who received concurrent chemoradiotherapy (CRT). Their data showed that higher serum HE4 levels are associated with poor response to CRT, shorter relapse-free and overall survival. ${ }^{21}$ Recently, Huang et al. evaluated the diagnostic and prognostic performance of HE4 in patients with NSCLC. They investigated both the short and the long-term prognostic efficacy of HE4 and indicate HE4 as a potential biomarker for diagnosis and follow-up of NSCLC patients. ${ }^{22}$

In our study, the serum HE4 concentration significantly decreased following pulmonary resection regardless of the histopathologic type $(\mathrm{p}<0.001)$, which was was more noticeable in advanced stages $(p=0.025)$. Thus, we believe HE4 levels could also be used to monitor NSCLC recurrences and treatment response during follow-up.

This present study had limitations that should be addressed. First, the study was conducted at a single center in Turkey, which may limit generalizability of the results to larger populations. Secondly, the sample size was relatively small. Thirdly, the follow-up period was only 1 month and thus, the role of HE4 in the prognosis of resected NSCLC patients were not analyzed.

In conclusion, our study demonstrated that HE4 is a potential biomarker for the diagnosis of NSCLC with high sensitivity and specificity and besides could be used to detect recurrences following resection. However, our data deserve further verification with multi-center and larger scale prospective trials.

\section{REFERENCES}

1. Group NM-aC, Arriagada R, Auperin A, et al. Adjuvant chemotherapy, with or without postoperative radiotherapy, in operable non-small-cell lung cancer: two meta-analyses of individual patient data. Lancet 375: 1267-1277, 2010.
2. Jiang $Y$, Wang $C$, Lv B, et al. Expression level of serum human epididymis 4 and its prognostic significance in human non-small cell lung cancer. Int J Clin Exp Med 7: 5568-5572, 2014.

3. Morgensztern D, Ng SH, Gao F, Govindan R. Trends in stage distribution for patients with non-small cell lung cancer: a National Cancer Database survey. J Thorac Oncol 5: 29-33, 2010.

4. Jemal A, Siegel R, Ward E, et al. Cancer statistics, 2009. CA Cancer J Clin 59: 225-249, 2009.

5. Kulpa J, Wojcik E, Reinfuss M, Kolodziejski L. Carcinoembryonic antigen, squamous cell carcinoma antigen, CYFRA 211 , and neuron-specific enolase in squamous cell lung cancer patients. Clin Chem 48: 1931-7, 2002.

6. Zeng Q, Liu M, Zhou N, et al. Serum human epididymis protein 4 (HE4) may be a better tumor marker in early lung cancer. Clin Chim Acta 455: 102-106, 2016.

7. Escudero JM, Auge JM, Filella X, et al. Comparison of serum human epididymis protein 4 with cancer antigen 125 as a tumor marker in patients with malignant and nonmalignant diseases. Clin Chem 57: 1534-1544, 2011.

8. Karlsen NS, Karlsen MA, Hogdall CK, Hogdall EV. HE4 tissue expression and serum HE4 levels in healthy individuals and patients with benign or malignant tumors: a systematic review. Cancer Epidemiol Biomarkers Prev 23: 2285-95, 2014.

9. Bingle L, Cross SS, High AS, et al. WFDC2 (HE4): a potential role in the innate immunity of the oral cavity and respiratory tract and the development of adenocarcinomas of the lung. Respir Res 7: 61, 2006.

10. Galgano MT, Hampton GM, Frierson HF, Jr. Comprehensive analysis of HE4 expression in normal and malignant human tissues. Mod Pathol 19: 847-853, 2006.

11. Howington JA, Blum MG, Chang AC, et al. Treatment of stage I and II non-small cell lung cancer: Diagnosis and management of lung cancer, 3rd ed: American College of Chest Physicians evidence-based clinical practice guidelines. Chest 143(5 Suppl): e278S-313S, 2013.

12. al-Kattan K, Sepsas E, Fountain SW, Townsend ER. Disease recurrence after resection for stage I lung cancer. Eur J Cardiothorac Surg 12: 380-384, 1997.

13. Hotta K, Fujiwara $\mathrm{Y}$, Kiura K, et al. Relationship between response and survival in more than 50,000 patients with advanced non-small cell lung cancer treated with systemic chemotherapy in 143 phase III trials. J Thorac Oncol 2: 402407, 2007.

14. Hertlein L, Stieber P, Kirschenhofer A, et al. Human epididymis protein 4 (HE4) in benign and malignant diseases. Clin Chem Lab Med 50: 2181-2188, 2012.

15. Yamashita S, Tokuishi K, Hashimoto T, et al. Prognostic significance of HE4 expression in pulmonary adenocarcinoma. Tumour Biol 32: 265-271, 2011.

16. Iwahori K, Suzuki H, Kishi $Y$, et al. Serum HE4 as a diagnostic and prognostic marker for lung cancer. Tumour Biol 33: 1141-1149, 2012. 
International Journal of Hematology and Oncology

17. Dikmen E, Gungor A, Dikmen ZG, Akbiyik F. Diagnostic Efficiency of HE4 and CYFRA 21-1 in Patients with Lung Cancer. UHOD 25: 44-50, 2015.

18. Liu W, Yang J, Chi PD, et al. Evaluating the clinical significance of serum HE4 levels in lung cancer and pulmonary tuberculosis. Int J Tuberc Lung Dis 17: 1346-1353, 2013.

19. Cheng $D$, Sun $Y, H e H$. The diagnostic accuracy of HE4 in lung cancer: a meta-analysis. Dis Markers 2015: 352670 , 2015. doi: 10.1155/2015/352670.

20. Chu XY, Hou XB, Song WA, et al. Diagnostic values of SCC, CEA, Cyfra21-1 and NSE for lung cancer in patients with suspicious pulmonary masses: a single center analysis. Cancer Biol Ther 11: 995-1000, 2011.

21. Lan WG, Hao YZ, Xu DH, et al. Serum human epididymis protein 4 is associated with the treatment response of concurrent chemoradiotherapy and prognosis in patients with locally advanced non-small cell lung cancer. Clin Transl Oncol 18: 375-380, 2016.

22. Huang W, Wu S, Lin Z, et al. Evaluation of HE4 in the diagnosis and follow up of non-small cell lung cancers. Clin Lab 63: 461-467, 2017.

\section{Correspondence:}

Dr. Ulaş KUMBASAR

Hacettepe Üniversitesi Tip Fakültesi

Kardiyovasküler ve Torasik Cerrahi Anabilim Dali

Sihhiye, ANKARA / TURKEY

Tel: (+90-312) 30517 74,

Fax: (+90-312) 3117377

e-mail: ulaskumbasar@gmail.com 